\title{
Controlled-Release Fertilizer on Growth of Melanoxylon brauna Schott Seedlings
}

\author{
Elbya Leão Gibson ${ }^{1}$ (D), Elzimar de Oliveira Gonçalves ${ }^{1}$ (D), \\ Aline Ramalho Dos Santos ${ }^{1}$ (D), Emanuel França Araújo ${ }^{1}$ (D), \\ Marcos Vinicius Winckler Caldeira ${ }^{1}$ (D) \\ ${ }^{1}$ Programa de Pós-graduação em Ciências Florestais, Universidade Federal do Espírito Santo - UFES, \\ Jerônimo Monteiro/ES, Brasil
}

\begin{abstract}
Melanoxylon brauna is a tree species native to the Atlantic Forest of high ecological and economic value. The objective of this study was to evaluate the growth and nutritional status of seedlings of two Melanoxylon brauna cultivars grown in substrate with different controlled-release fertilizer doses (CRF). The experiment was arranged in a randomized block $4 \times 2$ factorial design, with four CRF doses $\left(0,2,4\right.$, and $\left.8 \mathrm{~kg} \mathrm{~m}^{-3}\right)$ and two seed origins (Viçosa-MG and Linhares-ES), with four replicates and 126 seedlings per plot. At 60, 90, and 120 days after emergence, seedlings were collected to measure variables related to emergence, growth, and nutrition. The greatest growth and best nutritional status were found for seedlings originated from seeds collected in Linhares at CRF dose of $8 \mathrm{~kg} \mathrm{~m}^{-3}$. On the other hand, seedlings originated from seeds collected in Viçosa showed low emergence and high plant mortality.
\end{abstract}

Keywords: brauna, plant propagation, forestry, forest legume, forest nutrition. 


\section{INTRODUCTION}

Melanoxylon braunaSchott(Fabaceae-Caesalpinioideae), common name brauna, is a tree native to the Atlantic slope rainforest of the Northeastern and Southeastern regions of Brazil (Lorenzi, 2008). The species was described by Brito \& Carvalho (2014) as a late secondary and has great ecological and economic importance. Adult individuals are typically between 15 and $20 \mathrm{~m}$ in height and 40 to $80 \mathrm{~cm}$ in diameter (Lorenzi, 2008). The wood has recognized quality and durability, dark brown nearly black color in mature trees, and great economic value (Lorenzi, 2008).

Intense exploitation and lack of reforestation have led the species to be included in the official list of Brazilian flora threatened with extinction, with few forest fragments remaining with individuals of this species, which are usually small and isolated. Carvalho et al. (2007) reported that $M$. brauna has rarely been recorded in floristic surveys, which threatens the species conservation and warns of the need to preserve forest fragments with specific floristic diversity.

In spite of the great environmental value and potential for $M$. brauna lumber, there is lack of information on its forestry practices. Reports on means and strategies of $M$. brauna propagation is scarce in literature, therefore studies addressing seed technology, seminal or clonal seedling production, and initial growth in the field are urgently needed.

Controlled-release fertilizers (CRF) is a technology in fertilizer industry that has been increasingly used in tree seedling producing nurseries. Although costly, CRF technology has clear advantages to reduce production costs due to better area utilization as a result of reduction in crop cycle, labor, and operations, as well as optimization of space, water, and energy.

Controlled-release fertilizers technology consist of encapsulated materials coated by polymers deliberately made to allow for slow release of the active nutrient, maintaining prolonged nutrient release in synchronization with plant metabolic needs. CRF technology is designed to have optimal nutrient release, that is, the nutrient release rate corresponds to the maximum rate of nutrient uptake by plants, which varies dynamically during the plant growth stages over the growing season (Irfan et al., 2018).

Therefore, the objective of this study was to analyze the growth, quality, and nutritional status of seedlings of two M. brauna cultivars grown in substrate with different rates of controlled-release fertilizer (CRF). The hypothesis tested was that CRF doses influence the growth and nutrition of $M$. brauna seedlings from two origins.

\section{MATERIAL AND METHODS}

The experiment was conducted in a forest nursery located in the experimental area of the Department of Forestry and Wood - Federal University of Espírito Santo (DCFM-CCA-UFES) $\left(20^{\circ} 47^{\prime} \mathrm{S}\right.$ latitude and $41^{\circ} 23^{\prime} \mathrm{W}$ longitude, $120 \mathrm{~m}$ a.s.l.), in the municipality of Jerônimo Monteiro, ES, from July to November, 2017. The climate of the region is Cwa (dry winter and rainy summer), according to Köppen classification, with $24.1{ }^{\circ} \mathrm{C}$ annual average temperature and $1104 \mathrm{~mm}$ average annual rainfall (Maia et al., 2007).

M. brauna seeds were purchased from companies licensed from the Ministry of Agriculture, Livestock and Supply (MAPA), with the assurance that they were collected in the municipalities of Viçosa, Minas Gerais, Brazil, and Linhares, Espírito Santo, Brazil (Table 1).

The experiment was arranged in a randomized block $4 \times 2$ factorial design, with four CRF doses $\left(0,2,4\right.$, and $\left.8 \mathrm{~kg} \mathrm{~m}^{-3}\right)$ and two seed origins (Viçosa-MG and Linhares-ES), with four replicates and 126 seedlings per plot.

Table 2 shows the physicochemical characteristics of CRF Basacote ${ }^{\circledR}$ Mini 6M, with 13-6-16 formulation. Each experimental unit consisted of 126 seedlings, totaling 4032 initial plots.

Table 1. Climate data of Viçosa-MG and Linhares-ES.

\begin{tabular}{|c|c|c|c|c|c|c|c|}
\hline Municipality & $\begin{array}{c}\text { Köppen } \\
\text { Classification } \\
\end{array}$ & $\begin{array}{l}\text { Average } \\
\text { rainfall }\end{array}$ & $\begin{array}{l}\text { Days per } \\
\text { year with }\end{array}$ & $\begin{array}{c}\text { Average } \\
\text { compensated }\end{array}$ & Average & $\begin{array}{l}\text { Relative } \\
\text { humidity }\end{array}$ & Sunshine \\
\hline & (1948) & $\left(\mathrm{mm}\right.$ year $\left.^{-1}\right)$ & rainfall & temperature & & $(\%)$ & hours \\
\hline Viçosa & Cwa & 1289 & 92 & 20.1 & 690 & 80.3 & 2.098 .2 \\
\hline Linhares & Aw & 1267 & 116 & 24.0 & 33 & 83 & 2.182 .3 \\
\hline
\end{tabular}


Table 2. Physicochemical characteristics of the controlled-release fertilizer.

\begin{tabular}{|c|c|c|c|c|c|c|c|c|c|c|}
\hline $\mathbf{N}$ & $\mathbf{P}_{2} \mathbf{O}_{5}$ & $\mathrm{~K}_{2} \mathrm{O}$ & Mg & S & $\mathrm{Fe}$ & $\mathrm{Cu}$ & Mn & Mo & Grain diameter & 1000 seed weight \\
\hline & & & & $\%$ & & & & & $\mathrm{Mm}$ & g \\
\hline 13.00 & 6.00 & 16.00 & 1.40 & 10.00 & 0.26 & 0.05 & 0.06 & 0.015 & $1.5-2.5$ & 9.58 \\
\hline
\end{tabular}

Source: Manufacturer.

Table 3. Physicochemical characterization of the substrate.

\begin{tabular}{|c|c|c|c|c|c|c|c|c|}
\hline pH & $\mathbf{N}$ & $\mathbf{P}$ & $\mathbf{K}$ & $\mathrm{Ca}$ & $\mathrm{Mg}$ & $\mathbf{S}$ & $\mathrm{CE}$ & Density \\
\hline$\left(\mathrm{H}_{2} \mathrm{O}\right)$ & \multicolumn{6}{|c|}{$\mathrm{g} \mathrm{kg}^{-1}$} & $\mathrm{mS} \mathrm{cm}^{-1}$ & $\mathrm{~g} \mathrm{~cm}^{-3}$ \\
\hline 6.2 . & 11.5 & 9.0 & 5.2 & 15.0 & 7.2 & 4.5 & 0.4 & 0.35 \\
\hline
\end{tabular}

The different CRF doses were added to the commercial substrate (Pinus bark, vermiculite, agroindustrial organic waste class A, wood sawdust, horse manure, NPK; 55\% moisture) before filling of tubes, so that all received equal amounts of granules, according to each treatment. Samples were collected from the substrate prior to experiment installation for chemical characterization (Table 3 ).

Seeds were sown at depth of $0.3 \mathrm{~cm}$ in $280-\mathrm{cm}^{3}$ polypropylene tubes (external dimension: $64.5 \mathrm{~mm}$; internal dimension: $52 \mathrm{~mm}$; height: $190 \mathrm{~mm}$ ), one seed per tube, and placed on benches under $50 \%$ shade intensity. Seed dormancy breaking was carried out by mechanical scarification with 120 grit sandpaper until visible tegument wear on the opposite side to the hilum. Seeds were disinfested by agitation in $70 \%$ alcohol for one minute, then in sodium hypochlorite solution (2\%) for five minutes and rinsed three times in distilled water.

Emergence (E, in percentage \%) was calculated by equation proposed in Seed Analysis Guidelines (Brasil, 2009). Speed of emergence index (SEI), considering emerged seedlings those with cotyledons completely above substrate level, and mean emergence time (MET, days) were analyzed.

At 60, 90 and 120 days after emergence (DAE), the following variables were determined: mortality $(\mathrm{M}$, in percentage, \%); shoot height $(\mathrm{H}, \mathrm{cm})$, from the collar (at ground level) to the base of the highest leaf, with a ruler; collar diameter $(\mathrm{CD}, \mathrm{mm})$, at the edge of the tube, with digital caliper; the increase in $\mathrm{H}$ and $\mathrm{CD}$ at 90 and $120 \mathrm{DAE}$ by subtracting values observed on the previous month from those at the evaluation time; leaf number (LN), by counting the number of visible leaves; leaf chlorophyll content (CFT, ug $\mathrm{cm}^{-2}$ ), by sampling middle leaves on seedlings with SPAD-502 portable chlorophyll meter.

To determine shoot dry mass (SDM; g) and root dry mass (RDM; g), four seedlings were randomly collected per replicate at $120 \mathrm{DAE}$ and separated into shoot and root. Roots were washed from soil with tap water and length of the main root was measured with a ruler $(\mathrm{RL}, \mathrm{cm})$. The material was packed in brown paper bags and placed in a forced air oven at $65^{\circ} \mathrm{C}$ to constant weight. SDM and RDM were weighed using analytical scale (0.0001 $\mathrm{g}$ accuracy). TDM ( $\mathrm{g} \mathrm{plant}^{-1}$ ) corresponded to the sum of SDM and RDM. These variables were used to determine the Díckson Quality Index (DQI).

After oven drying, SDM of plants was milled in a stainless steel Willey ${ }^{\circledR}$ mill and sieved through a 20-mesh sieve to determine the nutritional content of phosphorus ( $\left.\mathrm{Pg} \mathrm{kg}^{-1}\right)$, calcium $(\mathrm{Ca})$, magnesium $(\mathrm{Mg})$, and sulfur $\left(\mathrm{S}^{1}\right)$. The accumulation of each nutrient in shoots was obtained by multiplying the nutrient content by SDM.

Data were analyzed by analysis of variance and when significant differences were verified by the $\mathrm{F}$ test at $5 \%$, means of the two origins were compared by the Tukey test at $5 \%$ and $1 \%$ probability levels and fertilizer doses were submitted to regression analysis to determine the optimum CRF dose for each variable, using the first derivative of estimators $\beta 0$ and $\beta 1$. Equations were chosen based on the significance of parameters, t-test, biological meaning and realism of models (linear and quadratic), and determination coefficient $\left(\mathrm{R}^{2}\right)$. The software used to analyze data was SISVAR 5.4 (Ferreira, 2014). 


\section{RESULTS}

The analysis of variance (Table 4 ) showed isolated effect ( $\mathrm{p} \leq 0.05$ ) of $M$. brauna seed origin for ESI, E, M 90 DAE, and M 120 DAE. Seeds from Viçosa-MG had low ESI, with very low final emergence percentage, which, together with the high mortality of the few individuals surviving at 90 and $120 \mathrm{DAE}$, made the continuity of the experiment with this origin unfeasible. It was found that CRF doses had no effect ( $p>0.05$ ) on variables related to the emergence of $M$. brauna seedlings.
CRF doses showed no significant influence $(\mathrm{p}>0.05)$ on $\mathrm{H}$ of $M$. brauna seedlings from Linhares-ES at 60 days; however, they promoted an increasing linear growth $(\mathrm{p} \leq 0.05)$ at 90 and 120 days after emergence. The maximum increase in $\mathrm{H}$ between 60 and 90 DAE (7.94 $\mathrm{cm}$ plant $^{-1}$ month $\left.^{-1}\right)$ was obtained at CRF dose of $7.12 \mathrm{~kg} \mathrm{~m}^{-3}$ (Table 5). The best fit for the increase in $\mathrm{H}$ between 90 and $120 \mathrm{DAE}$ was quadratic, where the maximum height of $5.34 \mathrm{~cm} \mathrm{plant}^{-1}$ month $^{-1}$ was obtained with CRF dose of $7.12 \mathrm{~kg} \mathrm{~m}^{-3}$.

Table 4. Analysis of variance and mean test for emergence speed index (ESI), emergence (E,\%), mean emergence time (MET, days), and mortality at 60, 90, and 120 days (M, \%) after sowing Melanoxylon brauna seeds of two origins submitted to different CRF doses.

\begin{tabular}{|c|c|c|c|c|c|c|c|}
\hline \multirow{3}{*}{ SV } & \multirow{3}{*}{ DF } & \multicolumn{6}{|c|}{ Mean square } \\
\hline & & \multirow{2}{*}{ ESI } & $\mathbf{E}$ & MET & M 60 & M 90 & M 120 \\
\hline & & & $(\%)$ & (days) & $(\%)$ & $(\%)$ & (\%.) \\
\hline Origin & 3 & $1.209^{\star \star}$ & $82.34^{\star *}$ & $0.6980^{\mathrm{ns}}$ & $2.771^{\mathrm{ns}}$ & $24.577^{\star}$ & $107.534^{\star}$ \\
\hline Rate & 1 & $0.0057^{\text {ns }}$ & $0.230^{\text {ns }}$ & $0.2609^{\text {ns }}$ & $4.085^{\mathrm{ns}}$ & $5.901^{\text {ns }}$ & $3.109^{\text {ns }}$ \\
\hline $\mathrm{D} \times \mathrm{P}$ & 3 & $0.012^{\mathrm{ns}}$ & $0.701^{\mathrm{ns}}$ & $0.340^{\text {ns }}$ & $2.345^{\mathrm{ns}}$ & $3.806^{\mathrm{ns}}$ & $5.504^{\mathrm{ns}}$ \\
\hline Block & 3 & $0.014^{\mathrm{ns}}$ & $0.727^{\mathrm{ns}}$ & $0.3185^{\mathrm{ns}}$ & $17.44^{\mathrm{ns}}$ & $2.324^{\mathrm{ns}}$ & $4.101^{\mathrm{ns}}$ \\
\hline Error & 21 & 0.0059 & 0.321 & 0.300 & 4.649 & 8.319 & 2.584 \\
\hline $\mathrm{CV} \%$ & & 6.08 & 15.35 & 13.98 & 60.93 & 52.15 & 22.05 \\
\hline Mean ES & & $1.160 \mathrm{a}$ & $27.48 \mathrm{a}$ & $15.59 \mathrm{a}$ & $14.84 \mathrm{a}$ & $21.90 \mathrm{a}$ & $29.48 \mathrm{a}$ \\
\hline Mean MG & & $0.162 \mathrm{~b}$ & $3.67 \mathrm{~b}$ & $13.81 \mathrm{a}$ & $18.95 \mathrm{a}$ & $51.97 \mathrm{~b}$ & $87.29 \mathrm{~b}$ \\
\hline
\end{tabular}

${ }^{*}$ and ${ }^{* *}=$ significant at level of $5 \%$ and $1 \%$ probability by the test $\mathrm{F}$ respectively; ns = non significant at $5 \%$ probability.

Table 5. Estimates based on the effect of controlled-release fertilizer doses on variables height $(\mathrm{H}, \mathrm{cm})$, increment (Inc, cm), collar diameter CD, mm), leaf number (LN), and leaf chlorophyll (LC) of Melanoxylon brauna seedlings.

\begin{tabular}{|c|c|}
\hline Variable & Equation \\
\hline
\end{tabular}

\begin{tabular}{|c|c|c|c|c|}
\hline H 60 & $\mathrm{~ns}=(\hat{\mathrm{Y}}=\overline{\mathrm{Y}}=3.21)$ & - & - & - \\
\hline H 90 & $\hat{\mathrm{Y}}=5.132+0.7924 * * \mathrm{x}$ & 0.88 & 8.00 & $11.47 \mathrm{~cm}$ plant $^{-1}$ \\
\hline $\mathrm{H} 120$ & $\hat{\mathrm{Y}}=6.5702+1.3377 * * \mathrm{x}$ & 0.86 & 8.00 & $17.27 \mathrm{~cm} \mathrm{plant}^{-1}$ \\
\hline Inc $\mathrm{H} 90$ & $\hat{\mathrm{Y}}=2.1597+0.7229 * * \mathrm{x}$ & 0.86 & 8.00 & $7.94 \mathrm{~cm}$ plant $^{-1} \mathrm{momth}^{-1}$ \\
\hline Inc $\mathrm{H} 120$ & $\hat{\mathrm{Y}}=0.7057+1.303 * * \mathrm{x}-0.09145 * \mathrm{x}^{2}$ & 0.97 & 7.12 & $5.34 \mathrm{~cm}$ plant $^{-1} \mathrm{momth}^{-1}$ \\
\hline CD 60 & $\mathrm{~ns}(\hat{\mathrm{Y}}=\overline{\mathrm{Y}}=1.61)$ & - & - & - \\
\hline $\mathrm{CD} 90$ & $\hat{\mathrm{Y}}=1.4835+0.1297 * * \mathrm{x}$ & 0.83 & 8.00 & $2.52 \mathrm{~mm}_{\text {plant }}^{-1}$ \\
\hline CD 120 & $\hat{\mathrm{Y}}=1.82745+0.17524 * * \mathrm{x}$ & 0.81 & 8.00 & $3.22 \mathrm{~mm}_{\text {plant }}{ }^{-1}$ \\
\hline Inc DC90 & $\hat{\mathrm{Y}}=0.181+0.2904 * * \mathrm{x}-0.0239 * * \mathrm{x}^{2}$ & 0.98 & 6.07 & $1.06 \mathrm{~mm}$ plant $^{-1} \mathrm{momth}^{-1}$ \\
\hline Inc DC120 & $\hat{\mathrm{Y}}=0.258716+0.1335 * * \mathrm{x}-0.0239 * * \mathrm{x}^{2}$ & 0.98 & 6.28 & $0.67 \mathrm{~mm}$ plant $^{-1} \mathrm{momth}^{-1}$ \\
\hline LN 60 & $\mathrm{~ns}(\hat{\mathrm{Y}}=\overline{\mathrm{Y}}=9.86)$ & - & - & - \\
\hline LN 90 & $\hat{\mathrm{Y}}=4.968+2.055 * * \mathrm{X}-0.149311 * * \mathrm{x}^{2}$ & 0.99 & 6.88 & 12.03 Un. plant ${ }^{-1}$ \\
\hline LN 120 & $\hat{\mathrm{Y}}=5.139+2.518 * * \mathrm{x}-0.1887 * * \mathrm{x}^{2}$ & 0.99 & 6.67 & 13.54 Un. plant ${ }^{-1}$ \\
\hline LC 60 & $\hat{\mathrm{Y}}=25.97805+1.21621 * * \mathrm{x}$ & 0.84 & 8.00 & $35.70 \mathrm{ug} \mathrm{cm}^{2}$ plant \\
\hline LC 90 & $\hat{Y}=28.159+3.137 * x-0.2786 * x^{2}$ & 0.97 & 5.62 & 36.99 ug cm$^{2}$ plant \\
\hline LC 120 & $\hat{\mathrm{Y}}=21.079+4.767 * * \mathrm{x}-0.37243 * * \mathrm{x}^{2}$ & 0.99 & 6.39 & $36.33 \mathrm{ug} \mathrm{cm}^{2}$ plant \\
\hline
\end{tabular}

${ }^{*}$ and ${ }^{* *}=$ significant at $5 \%$ and $1 \%$ of probability levels by the test $\mathrm{F}$ respectively; ns $=$ non significant at $5 \%$ probability. 
Table 6. Estimates based on the effect of controlled-release fertilizer doses on variables root length (RL, cm), shoot dry mass (SDM, g), root dry mass (RDM, g), total dry mass (TDM, g), Dickson quality index (DQI), and nutrient accumulation $(\mathrm{A}, \mathrm{mg})$ of phosphorus $(\mathrm{P})$, calcium $(\mathrm{Ca})$, magnesium $(\mathrm{Mg})$, and sulfur in the shoots $(\mathrm{SH})$ of Melanoxylon brauna seedlings from Linhares-ES at 120 DAE.

\begin{tabular}{llccc}
\multicolumn{1}{c}{ Variable } & \multicolumn{1}{c}{ Equation } & $\mathbf{R}^{2}$ & Optimal dose & Estimated maximum value \\
RL & $\hat{\mathrm{Y}}=18.2150+2.0725 * * \mathrm{x}$ & 0.86 & 8.00 & $34.79 \mathrm{~cm} \mathrm{plant}^{-1}$ \\
SDM & $\hat{\mathrm{Y}}=0.11788+0.412254^{* *} \mathrm{x}$ & 0.99 & 8.00 & $3.41 \mathrm{~g} \mathrm{plant}^{-1}$ \\
RDM & $\hat{\mathrm{Y}}=-0.00991+0.08763 * * \mathrm{x}$ & 0.98 & 8.00 & $0.69 \mathrm{~g} \mathrm{plant}^{-1}$ \\
TDM & $\hat{\mathrm{Y}}=0.10797+0.49989 * * \mathrm{x}$ & 0.99 & 8.00 & $4.10 \mathrm{~g} \mathrm{plant}^{-1}$ \\
DQI & $\hat{\mathrm{Y}}=0.00617+0.04851^{*} \mathrm{x}$ & 0.99 & 8.00 & 0.39 \\
APSH & $\hat{\mathrm{Y}}=0.83857+1.9081 * * \mathrm{x}$ & 0.78 & 8.00 & $16.10 \mathrm{mg} \mathrm{plant}^{-1}$ \\
ACaSH & $\hat{\mathrm{Y}}=0.5143+2.2617 * * \mathrm{x}$ & 0.79 & 8.00 & $18.60 \mathrm{mg} \mathrm{plant}^{-1}$ \\
AMgSH & $\hat{\mathrm{Y}}=0.0396+0.5605 * * \mathrm{x}$ & 0.81 & 8.00 & $4.52 \mathrm{mg} \mathrm{plant}^{-1}$ \\
ASSH & $\hat{\mathrm{Y}}=0.079096+0.5833^{*} \mathrm{x}$ & 0.96 & 8.00 & $4.74 \mathrm{mg} \mathrm{plant}^{-1}$ \\
\hline
\end{tabular}

** $=$ significant at the level of $5 \%$ and $1 \%$ of probability by the test $\mathrm{F}$ respectively; ns = non significant at $5 \%$ probability.

There was no significant difference $(\mathrm{p}>0.05)$ among CRF doses for increase in CD of M. brauna seedlings at 60 DAE. However, at 90 and 120 DAE, regardless of CRF dose, increase in CD of M. brauna seedlings was higher than the mean increase of control seedlings, without CRF incorporated into the substrate. The growth trend was linearly increasing at 90 and 120 days (Table 5). The increase in CD was greater from 60 to 90 days and CRF dose of $6.07 \mathrm{~kg} \mathrm{~m}^{-3}$ promoted the highest growth in this period. Thus, it is possible to infer that plants of this species are very responsive to initial fertilization in the seedling phase, mainly at 60 DAE.

The quadratic model provided the best explanation of the effect of CRF doses at ages of 90 and 120 DAE on leaf number (LN), with maximum yields of 12.03 and 13.54 leaf plant ${ }^{-1}$ obtained with CRF dosesd of 6.88 and $6.67 \mathrm{~kg} \mathrm{~m}^{-3}$. Leaf chlorophyll (LC) showed two growth trends: at $60 \mathrm{DAE}$, growth was linearly increasing, and at 90 and $120 \mathrm{DAE}$, growth was quadratic and optimal CRF doses were 5.62 and $6.39 \mathrm{~kg} \mathrm{~m}^{-3}$ (Table 5).

For root length (RL), the production of SDM, RDM, TDM, and DQI had predominant linearly increasing behavior, achieving the highest means at CRF dose of $8.00 \mathrm{~kg} \mathrm{~m}^{-3}$ (Table 6).

The nutritional evaluation of phosphorus, calcium, magnesium, and sulfur showed the same trend, in which CRF dose of $8.00 \mathrm{~kg} \mathrm{~m}^{-3}$ promoted the greatest accumulation of nutrients in SDM of Melanoxylon brauna seedlings (Table 6).

\section{DISCUSSION}

The results for variable emergence of $M$. brauna from Viçosa-MG suggest that there might be problems of viability and/or storage of seeds, since the emergence percentage was very low. Literature reports add support to this explanation, showing that the species has large temperature range for germination, from 12.1 to $43^{\circ} \mathrm{C}$, and optimum temperature of $27^{\circ} \mathrm{C}$, which was confirmed by the electrical conductivity test (Flores et al., 2014). In this study, seeds were germinated in July, and at this time, the average temperatures were possibly below this value. However, Borges et al. (2015), analyzing germination and vigor responses of $M$. brauna seeds (from Leopoldina, MG) to eight-month storage under relative humidity of 55,75 , and $93 \%$ and temperature of $20^{\circ} \mathrm{C}$, found that the germination speed and percentage decrease with increasing water level in the environment, and in storage environments with 75 and $93 \%$, seeds tend to die due to stressful moisture conditions.

Another possible explanation would be related to the natural geographical distribution of M. brauna. According to Dyer et al. (2007), species from tropical regions are exposed to adverse edaphoclimatic conditions, and this environmental heterogeneity combined with natural selection results in genetically distinct populations. Thus, in forest restoration projects, the introduction of non-local populations may bring problems for the survival of these individuals, which may not be well adapted to the environmental conditions of the new site compared with local genotypes, and such adaptation is referred to as fitness (Humphrey \& Schupp, 2002). 
The results of variables related to seedling growth and nutrition validated the hypothesis that CRF promotes the growth and nutritional status of M. brauna seedlings. The linear regression model adjusted for most variables did not allow predicting the optimum dose or maximum technical efficiency for the seedlings of this species. This result indicates that there may be even greater gains in the growth of seedlings of this species with application of higher CRF doses. It was found that under the conditions of this experiment, CRF dose of $8.00 \mathrm{~kg} \mathrm{~m}^{-3}$ promoted the highest growth and nutritional quality of $M$. brauna seedlings.

$\mathrm{H}, \mathrm{CD}, \mathrm{RDM}$, and TDM stand out as variables used to evaluate the growth and quality of tree seedlings and may be correlated with survival and growth of seedlings in the field. As CRF doses increased, significant gains were observed in nutrient accumulation in shoots, and increments at optimum doses $\left(8 \mathrm{~kg} \mathrm{~m}^{-3}\right)$ were 19.2 ; 36.1; 9.61 and 59.99 times greater for $\mathrm{P}, \mathrm{Ca}, \mathrm{Mg}$, and $\mathrm{S}$, respectively, than control without CRF.

In the recovery of degraded areas, high quality and well-nourished seedlings with maximum vigor in the nursery can establish more quickly in the field in adverse conditions, going through the early and critical growth stages more quickly. A vigorous root system can, in the field, recover and increase microbiological activity in the soil, in addition to contributing to biomass increase, favoring soil aggregation and structuring.

An important finding is that increases in $\mathrm{H}$ and $\mathrm{CD}$ at $120 \mathrm{DAE}$ were smaller than those at $90 \mathrm{DAE}$. This result may be due to the growth behavior of species at higher CRF doses, with seedlings having earlier limitation of space available in the tube, which may have influenced root growth and plant metabolism. This hypothesis is supported by observations in the experiment, as species grows a long pivotal root, which rapidly reaches the bottom of the tube and undergoes oxidation. This fact may also have resulted in increased mortality percentage in the period from 60 to $120 \mathrm{DAE}$. It is also worth noting that both maximum height of $17.27 \mathrm{~cm}$ and collar diameter of $3.22 \mathrm{~mm}$ at $120 \mathrm{DAE}$ were below values proposed by Gonçalves et al. (2000) as a good quality standard for seedlings of forest species.

Information is scarce on the production of M. brauna seedlings and the final stage in the nursery, when seedlings are sent to the field, thus, these studies are fundamental to compare optimal growth indices. In general, studies have shown that forest species respond positively to CRF addition to the substrate.
Navroski et al. (2016) found that cedar seedlings (Cedrelafissilis) show good growth when $5 \mathrm{~kg} \mathrm{~m}^{-3}$ of CRF are incorporated into the substrate. Rosa et al. (2018) verified improvement in growth of Moringa oleifera seedling when using controlled-release fertilizer at dose of $5.37 \mathrm{~kg} \mathrm{~m}^{-3}$ substrate.

This trend was also reported by Rossa et al. (2015), who verified that CRF application results in significant growth gains for cohoba tree (Anadenanthera peregrina) and Brazilian peppertree seedlings (Schinus terebinthifolius), with the best doses for cohoba tree between 5.54 and $6.68 \mathrm{~kg} \mathrm{~m}^{-3}$ and for Brazilian peppertree between 8.38 and $14.42 \mathrm{~kg} \mathrm{~m}^{-3}$. Dutra et al. (2016) concluded that yellow poinciana (Peltophorum dubium) seedlings responded to CRF, showing best growth and quality standard at doses between 5.4 and $8.2 \mathrm{~g} \mathrm{dm}^{-3}$.

There is increasing interest in information on silvicultural practices for Brazilian tree species, mainly after the country's commitment to the Paris Agreement, 2015 , to fight climate change by reforesting 12 million hectares by 2030. Despite remarkable advances in native forest silviculture, studies are needed to establish the optimal nutritional conditions for each cultivated species. Considering that increments for Melanoxylon brauna began to decrease over time, further studies should be carried out focusing on CRF doses higher than those tested in the present study and containers for seedling production with larger volume capacity and longer height.

\section{CONCLUSION}

Based on total dry mass, CRF dose of $8.00 \mathrm{~kg} \mathrm{~m}^{-3}$ is recommended to increase the growth in seedling production of M. brauna seeds originated from Linhares-ES.

\section{ACKNOWLEDGEMENTS}

The present work was carried out with the support of Coordenação de Aperfeiçoamento de Pessoal de Nível Superior - Brasil (CAPES) - Código de Financiamento 001; Fundação de Amparo à Pesquisa e Inovação do Espírito Santo (FAPES), Secretaria de Estado de Agricultura, Abastecimento, Aquicultura e Pesca do Estado do Espírito Santo (SEAG) and Rosal Energia through the Technical Cooperation Agreement Process No.: 23068.010686/2012-18. 


\section{SUBMISSION STATUS}

Received: 1 nov., 2018

Accepted: 4 dec., 2018

\section{CORRESPONDENCE TO}

\section{Elbya Leão Gibson}

Programa de Pós-graduação em Ciências

Florestais, Departamento de Ciências Florestais e da Madeira, Universidade Federal do Espírito

Santos - UFES, Av. Gov. Lindemberg, 316, Centro, CEP 29550-000, Jerônimo Monteiro, ES, Brasil

e-mail: elbyagibson@hotmail.com

\section{FINANCIAL SUPPORT}

Coordenação de Aperfeiçoamento de Pessoal de Nível Superior - Brasil (CAPES) - Código de Financiamento 001; Fundação de Amparo à Pesquisa e Inovação do Espírito Santo (FAPES), Secretaria de Estado de Agricultura, Abastecimento, Aquicultura e Pesca do Estado do Espírito Santo (SEAG); Rosal Energia Convênio de Cooperação técnica No de processo: 23068.010686/2012-18.

\section{REFERENCES}

Borges EEL, Flores AV, Ataíde GM, Matos ACB. Alterações fisiológicas e atividade enzimática em sementes armazenadas de Melanoxylonbrauna Schott. Cerne 2015; 21(1): 75-81. http://dx.doi.org/10.1590/01047760201521011569.

Brasil. Ministério da Agricultura, Pecuária e Abastecimento. Regras para análise de sementes. Brasília: Mapa; 2009.

Brito PS, Carvalho FA. Estrutura e diversidade arbórea da Floresta Estacional Semidecidual secundária no Jardim Botânico da Universidade Federal de Juiz de Fora. Rodriguésia 2014; 65(4): 817-830. http://dx.doi. org/10.1590/2175-7860201465402.

Carvalho FA, Nascimento MT, Braga JMA. Estrutura e composição florística do estrato arbóreo de um remanescente de Mata Atlântica submontana no município de Rio Bonito, RJ, Brasil (Mata Rio Vermelho). Revista Árvore 2007; 31(4): 717-730. http://dx.doi.org/10.1590/S010067622007000400017 .

Dutra TR, Massad MD, Sarmento MFQ, Matos PS, Oliveira JC. Fertilizante de liberação lenta no crescimento e qualidade de mudas de canafístula (Peltophorumdubium
(Spreng.) Taub.). Floresta 2016; 46(4): 491-498. http:// dx.doi.org/10.5380/rf.v46i4.44570.

Dyer LA, Singer MS, Lill JT, Stireman JO, Gentry GL, Marquis RJ et al. Host specificity of Lepidoptera in tropical and temperate forests. Nature 2007; 448(7154): 696-699. http://dx.doi.org/10.1038/nature05884. PMid:17687325.

Ferreira DF. Sisvar: a guide for its bootstrap procedures in multiple comparisons. Ciência e Agrotecnologia 2014; 38(2): 109-112. http://dx.doi.org/10.1590/S141370542014000200001 .

Flores AV, Borges EEDL, Guimarães VM, Ataíde GDM, Castro RVO. Germination of Melanoxylonbrauna schott seed in different temperatures. Revista Árvore 2014; 38(6): 1147-1154. http://dx.doi.org/10.1590/S010067622014000600019 .

Gonçalves JLM, Santarelli EG, Moraes SP No, Manara MP. Produção de mudas de espécies nativas: substrato, nutrição, sombreamento e fertilização. In: Gonçalves JLM, Benedetti V, editores. Nutrição e fertilização florestal. Piracicaba: IPEF; 2000.

Humphrey LD, Schupp EW. Seedling survival from locally and commercial obtained seeds on two semiarid sites. Restoration Ecology 2002; 10(1): 88-95. http://dx.doi. org/10.1046/j.1526-100X.2002.10109.x.

Irfan SA, Razali R, Kushaari K, Mansor N, Azeem B, Versypt ANF. A review of mathematical modeling and simulation of controlled-release fertilizers. Journal of Controlled Release 2018; 271(10): 45-54. http://dx.doi. org/10.1016/j.jconrel.2017.12.017. PMid:29274697.

Lorenzi H. Árvores brasileiras: Manual de identificação e cultivo de plantas arbóreas nativas do Brasil. 5. ed. Nova Odessa: Instituto Plantarum; 2008.

Maia AR, Lopes JC, Teixeira CO. Efeito do envelhecimento acelerado na avaliação da qualidade fisiológica de sementes de trigo. Ciência e Agrotecnologia 2007; 31(3): 678-684. http://dx.doi.org/10.1590/S1413-70542007000300012.

Navroski MC, Tonett EL, Mazzo MV, Frigotto T, Pereira MO, Galvani LV. Procedência e adubação no crescimento inicial de mudas de cedro. Pesquisa Florestal Brasileira 2016; 36(85): 17-24. http://dx.doi.org/10.4336/2016. pfb.36.85.966.

Rosa TLM, Jordaim RB, Alexandre RS, Araújo CP, Gonçalves FG, Lopes JC. Controlled release fertilizer in the growth of Moringa oleifera LAM. seedlings. Floresta 2018; 48(3): 303-310. http://dx.doi.org/10.5380/rf.v48i3.50063.

Rossa ÜB, Angelo AC, Westphalen DJ, Oliveira FEM, Silva FF, Araujo JC. Fertilizante de liberação lenta no desenvolvimento de mudas de Anadenanthera peregrina (L.) Speg. (angico-vermelho) e SchinusterebinthifoliusRaddi (aroeira-vermelha). Ciência Florestal 2015; 25(4): 841-852. http://dx.doi.org/10.5902/1980509820582. 